\title{
Perkawinan antara Warga Negara Indonesia dengan Pengungsi Asing: Tinjauan Legalitas
}

\author{
Shinta Abidasari \\ Fakultas Hukum Universitas Indonesia \\ shinta.abidasari@gmail.com
}

\begin{abstract}
Abstrak
Indonesia hingga saat ini masih menjadi salah satu negara transit bagi pencari suaka asing yang hendak menuju ke negara ketiga seperti Australia, Amerika Serikat dan sebagainya. Selama masa penantian ini, dampak sosial tidak dapat dihindari bagi Indonesia sebagai negara transit. Salah satunya yaitu perkawinan antara pencari suaka atau pengungsi dengan warga negara Indonesia. Meskipun hak atas perkawinan adalah salah satu hak dasar manusia, jenis perkawinan tersebut menjadi problematik karena perkawinan tersebut tidak bisa memenuhi persyaratan hukum Indonesia. Rumusan masalah bagaimana legalitas perkawinan antara warga negara Indonesia dengan pengungsi asing? Tujuan penelitian untuk melihat perkawinan jenis ini menjadi sah hanya karena salah satu pasangan berstatus pengungsi asing di Indonesia. Kegunaan penelitian ini memberikan informasi legalitas dari perkawinan antara pengungsi dan warga negara Indonesia. Metode penelitian deskriptif pendekatan normatif. Hasil penelitian bahwa perkawinan pada dasarnya harus dicatat agar terjamin kepastian dan perlindungan hukum bagi suami istri beserta akibat hukum. Pencatatan perkawinan merupakan suatu keharusan yang harus dipenuhi perkawinan begitu juga antara pengungsi asing dengan Warga Negara Indonesia. Pengungsi asing tidak memenuhi ketentuan tersebut dikarenakan tidak adanya pekerjaan dan tempat kediaman (domisili). Kesimpulan bahwa seorang pengungsi dalam hukum Indonesia tidak dapat melangsungkan perkawinan yang sah, hal ini disebabkan pengungsi tidak memiliki kejelasan tempat tinggal sehingga tidak dapat diterbitkan akta perkawinan sesuai dalam Pasal 12 PP Nomor 9 Tahun 1975.
\end{abstract}

Kata Kunci: Legalitas, perkawinan, pengungsi, warga negara Indonesia

\section{Marriage between Indonesian Citizens with Foreign Refugees : Legality Reviews}

\begin{abstract}
Indonesia is still one of the transit countries for asylum seekers who are trying to reach countries such as Australia, the United States and so on. During this waiting period, social impacts cannot be obtained for Indonesia as a transit country. One is the marriage between asylum seekers or refugees and Indonesian citizens. Because the right to marriage is one of the basic human rights, this type of marriage becomes problematic because this marriage cannot meet Indonesian legal requirements. The formulation of the problem of how is the legality of marriage between Indonesian citizens and foreign refugees? The purpose of this research is to see that this type of marriage becomes legal only because one of the couples is a refugee status in Indonesia. The usefulness of this research provides
\end{abstract}


information on the legality of marriages between refugees and Indonesian citizens. Descriptive research methods are normative inquiry. The results of research on marriage must be approved in order to guarantee certainty and legal protection for husbands Marriage registration is a necessity that must be issued by marriage as well as between refugees and Indonesian citizens. Foreign refugees do not meet these requirements because there are no jobs and residences. The conclusion that refugees in Indonesia cannot hold a legal marriage, this is due to the fact that the refugees do not have a perfect place so that they cannot issue a marriage certificate in accordance with Article 12 PP Number 9 of 1975.

Keywords: Legality, marriage, refugees, Indonesian citizens.

\section{Pendahuluan}

Salah satu permasalahan sosial dan hukum yang muncul atas keberadaan pengungsi asing di Indonesia adalah terjadinya perkawinan antara WNI dan pengungsi asing. (Muhammad Nuramdani, 23 Maret 2020: liputan6.com). Bahkan terdapat kasus dimana para pengungsi asing ini menjalin hubungan dengan WNI yang telah resmi menikah. (M. Syukur, 26 Maret 2020: liputan6.com). Lembaga swadaya masyarakat yang bergerak dibidang pengungsi (SUAKA) mencatat bahwa banyak juga terjadi perkawinan antar pengungsi yang terjadi di camp-camp salah satunya di Aceh. SUAKA juga mencatat temuan bahwa perkawinan antara pengungsi dan WNI banyak terjadi ketika WNI tersebut sedang menjadi Tenaga Kerja Wanita (TKW) di Malaysia. (LBH Jakarta, 2016:39).

Indonesia hingga saat ini selalu menjadi negara transit bagi para pengungsi asing yang secara tradisional ingin menuju negara Australia dan Selandia Baru. (Robyn C. Sampson, Sandra Gifford, dan Savitri Taylor. 2016:1132-1152). Selain Rohingya, Indonesia juga menjadi negara transit bagi pengungsi yang berasal dari Afghanistan dan negara lain dalam dua puluh terakhir ini. (Antje Missbach, 2015: 42-44). Hingga bulan Januari 2018, terdapat 13.895 pencari suaka yang terdaftar dan berada di Indonesia. (UNHCR, Januari 2018). Di Indonesia, mereka tinggal diberbagai tempat atau penampungan yang berbedabeda rumah detensi imigrasi, community houses, penampungan sementara dan tinggal secara mandiri. Pemerintah Indonesia hanya bertanggungjawab atas 
mereka yang tinggal di seluruh rumah detensi imigrasi dan di lembaga pemerintah lainnya.

Dalam rangka membantu kehidupan para pengungsi asing, Pemerintah Indonesia bekerjasama dengan UNHCR dan IOM untuk memproses atau melaksanakan "refugee status determination" (RSD) dan memberikan bantuan logistiknya. Bantuan logistik ini sangat penting mengingat para pengungsi asing ini berniat untuk tinggal sementara dan mereka tunduk pada sejumlah pembatasan menurut hukum Indonesia yang salah satunya adalah larangan untuk bekerja. Oleh karena itu, ketika proses penentuan status sebagai pengungsi dan proses penempatan ke negara ketiga tidak memiliki waktu yang jelas, para pengungsi asing ini harus menghidupi dirinya sendiri selama tinggal di Indonesia. (Yunizar Adiputera \& Atin Prabandari, 2018: 3).

Berbagai hasil dapat muncul dari interaksi antara para pengungsi dan masyarakat Indonesia. Masalah hukum dan sosial yang terjadi dalam masyarakat Indonesia biasanya melibatkan para pencari suaka dan mereka yang telah memperoleh status pengungsi yang hidup mandiri di luar pusat-pusat penahanan imigrasi dan rumah-rumah komunitas (community houses).

Salah satu permasalahan sosial dan hukum yang muncul atas keberadaan pencari suaka dan pengungsi ini adalah terjadinya perkawinan antara warga negara Indonesia (WNI) dengan pencari suaka atau pengungsi. Perkawinan yang dilangsungkan oleh mereka mengalami permasalahan di hadapan hukum Indonesia. Perkawinan ini tunduk kepada hukum yang berlainan dan tidak dapat disebut sebagai perkawinan campuran sebagaimana dimaksud oleh Pasal 57 UU No. 1 Tahun 1974. Disebut dengan tunduk pada hukum yang berlainan karena salah satu calon mempelai berkewarganegaraan asing dan calon mempelai yang lain berkewargnegaraan Indonesia. Perkawainan tersebut tidak termasuk katagori perkawinan campuran karena tidak terpenuhinya unsur perkawinan campuran yaitu perbedaan kewarganegaraan, dimana pengungsi asing tersebut tidak bisa menunjukkan secara dokumen hukum kewarganegaraan.

Meskipun terdapat unsur yang tidak dapat dipenuhi, namun dalam praktiknya perkawinan antara pengungsi asing dan WNI tetap dilaksanakan 
secara agama saja atau siri. Selain unsur "kewarganegaraan" yang tidak dapat dipenuhi terdapat unsur lain pula yang tidak dapat dipenuhi yaitu unsur dalam Pasal 2 ayat (2) Undang-Undang Perkawinan yaitu mengenai pencatatan kepada pegawai pencatat nikah. Sebagai konsekuensi tidak dilakukannya pencatatan tersebut maka tidak dapat dikeluarkannya akta nikah, yang mana akta nikah merupakan satu-satunya bukti otentik untuk peristiwa perkawinan. Di dalam akta nikah terdapat beberapa unsur yang harus dipenuhi yaitu salah satunya adalah mengenai pekerjaan dan tempat kediaman (domisili). Mengenai unsur pekerjaan dan tempat kediaman (domisili) ini tidak dimungkinkan bagi pengungsi untuk memperolehnya, hal ini dikarenakan Indonesia belum meratifikasi Konvensi 1951 tentang Perlindungan Pengungsi dan memang dilarang untuk memberikan unsur tersebut kepada pengungsi asing dalam kebijakan hukum Indonesia.

Dengan demikian dapat dikatakan bahwa menurut hukum Indonesia tidak dapat dilangsungkan pernikahan antara WNA dengan pengungsi atau fegugee. Hal ini disebabkan karena pengungsi asing tersebut berdasarkan ketentuan perundang-undangan yang berlaku di Indonesia tinggal secara tidak sah. Walaupun status sebagai pencari suaka atau status pencari suaka diberikan oleh UNHCR kepada pengungsi asing tersebut. Di samping tidak mungkin dilangsungkan pernikahan, pengungsi asing juga tidak diperkenankan untuk melakukan suatu kegiatan apapun (bekerja). Hal ini disebabkan karena pengungsi asing tersebut hanya diizinkan tinggal sementara saja di Indonesia sebelum dipindahkan ke negara ketiga.

Berdasarkan literatur yang ada, telah banyak yang mencoba untuk meneliti bagaimana keadaan para pencari suaka dan pengungsi di Indonesia (Fitria, 2015: 105-125). Sebagian besar kesimpulan yang didapat adalah Indonesia bukan negara tujuan dan akan selalu menjadi pilihan transit bagi pencari suaka yang menuju Australia atau negara lainnya (M Riadussyah, 2014: 59). Beberapa penelitian juga telah mencoba untuk mengkaitkan permasalahan perkawinan antara WNI dan pencari suaka dan pengungsi ini namun lebih banyak fokus dalam proses hak mendapatkan kewarganegaraan anak tanpa meneliti lebih 
lanjut bagaimana sebenarnya status hukum dari perkawinan campuran tersebut tidak memenuhi syarat formal menurut UU Perkawinan (Yuera Rizki Kaharudin, Sri Lestari Rahayu \& Ayyub Torry Satriyo Kusumo, 2018: 211).

Berdasarkan latar belakang tersebut, maka yang menjadi pokok permasalahan dalam penelitian ini yaitu bagaimana legalitas perkawinan antar warga negara Indonesia dengan pengungsi?

\section{Pembahasan}

\section{A. Perkawinan WNI dengan Pengungsi Asing Perkawinan Campuran}

Meskipun keberadaan pengungsi asing di Indonesia hanyalah sementara dan tidak dalam memiliki status hukum yang jelas, interaksi antara pengungsi asing yang sedang menunggu di Indonesia dengan masyarakat Indonesia secara umum merupakan suatu hal yang tidak dapat dihindari.

Pemerintah Indonesia hanya bertanggungjawab atas mereka yang tinggal di seluruh rumah detensi imigrasi dan di lembaga pemerintah lainnya. Mereka yang tinggal di tempat penampungan sementara dan community houses diberikan bantuan oleh International Organization of Migration (IOM) (Peraturan Direktorat Jenderal Imigrasi No. 0352.GR.02.07/2016). Akan tetapi, bagi mereka yang tinggal secara mandiri, tidak akan mendapatkan bantuan manapun karena mereka datang ke Indonesia secara legal namun kemudian menyatakan diri sebagai pencari suaka.

Para pengungsi sebagai pencari suaka datang dari luar Indonesia dan bukan warga negara Indonesia. Dalam penanganan isu pencari suaka ini pemerintah Indonesia menganggap tetap jatuh di bawah aturan keimigrasian. Indonesia pertama kali memberlakukan hukum imigrasi pada tahun 1992 tetapi kemudian digantikan oleh UU No. 6 Tahun 2011. Tanpa dokumen perjalanan yang sah, maka bagi mereka akan dikenakan sanksi dan penahanan imigrasi. Pasal 1 ayat (1) undang-undang ini mendefinisikan imigrasi sebagai hal atau kejadian sehubungan dengan lalu lintas orang yang memasuki atau meninggalkan wilayah Indonesia dan pengawasannya untuk melindungi penegakan kedaulatan negara Indonesia. Mengacu pada definisi ini, masuknya pencari suaka ke 
Indonesia atau keluarnya pengungsi yang ditempatkan di negara ketiga dapat dibangun sebagai masalah imigrasi. Ini juga mencakup pengawasan para pencari suaka dan pengungsi yang sedang menunggu penempatan di negara ketiga.

Di dalam UU No. 6 Tahun 2011, para pengungsi dapat diklasifikasikan sebagai warga negara asing. Karena orang asing itu bukan warga negara Indonesia, ketika ia masuk ke wilayah Indonesia, ia harus memiliki visa yang valid dan dokumen perjalanan yang sah atau yang lain. Jika dilanggar, mereka akan ditempatkan di rumah detensi imigrasi. Namun, khusus untuk pengungsi, undang-undang tidak menyebutkan tanggapan khusus kepada mereka. Ini hanya mengatur penanganan korban perdagangan manusia dan penyelundupan manusia yang bagi mereka dibebaskan dari tindakan administrasi imigrasi.

Imigran Ilegal yang berada di Indonesia sesungguhnya dimungkinkan untuk mendapatkan izin tinggal di Indonesia akan tetapi terdapat syarat yang harus dipenuhi yaitu telah diperolehnya Attestation Letter (surat keterangan sebagai pencari suaka) atau berstatus sebagai pengungsi yang dikeluarkan oleh UNHCR. UNHCR adalah organisasi internasional yang bertugas untuk melakukan perlindungan terhadap pengungsi secara global. UNHCR memiliki kantor di Indonesia dikarenakan terdapat pengungsi asing di Indonesia sementara Indonesia bukanlah negara anggota konvensi 1951. Oleh karena itu keberadaan UNHCR adalah untuk melakukan proses penilaian apakah pencari suaka memenuhi prasyarat sebagai pengungsi sesuai dengan konvensi 1951.

Kondisi ini menyebabkan situasi saat ini di mana Indonesia menjadi negara transit, pemrosesan, dan tempat menunggu bagi mereka yang mencari negara lain yang menerimanya. Beberapa ahli berpendapat bahwa para pengungsi ini hidup dalam limbo (keadaan tidak jelas) karena masa tunggu untuk diterima dinegara ketiga menjadi tidak pasti (periode menunggu yang lebih lama adalah sebuah kenyataan umum) (Joe Cochrane, 2018) dan mereka tidak memenuhi syarat untuk bekerja dan beberapa dari mereka hidup secara mandiri (Yunizar Adiputera \& Atin Prabandari, 2018: 3).

Seperti telah disebutkan pada alinea sebelumnya terdapat beberapa kasus perkawinan antara WNI dengan pengungsi asing. Hal menarik untuk dianalisis 
adalah apakah undang-undang perkawian Indonesia melegalkan perkawinan seperti ini. Sebab di Indonesia hanya dikenal dua macam perkawinan yaitu warga negara Indonesia dengan warga negara Indonesia atau warga negara Indonesia dengan warga negara asing yang mempunyai status kewarganegaraan. Sehingga perkawinan model seperti itu dalam tulisan ini akan dilihat apakah dapat dikategorikan sebagai "perkawinan campuran" menurut UU No. 1 Tahun 1971. Perkawinan campuran dinyatakan oleh Pasal 57 UU Perkawinan:

"Yang dimaksud dengan perkawinan campuran dalam Undang-undang ini ialah perkawinan antara dua orang yang di Indonesia tunduk pada hukum yang berlainan, karena perbedaan kewarganegaraan dan salah satu pihak berkewarganegaraan Indonesia".

Perkawinan ini akan menjadi sah menurut hukum Indonesia jika perkawinan tersebut dilangsungkan dan dicatatkan berdasarkan UU No. 1 Tahun 1971. Merujuk ketentuan pasal di atas, unsur perkawinan campuran yaitu:

1. Perkawinan antara dua orang yang di Indonesia;

2. Tunduk pada hukum yang berlainan, karena perbedaan kewarganegaraan;

3. Salah satu pihak berkewarganegaraan Indonesia.

Untuk menentukan apakah perkawinan antara WNI dengan pengungsi asing termasuk ke dalam kategori perkawinan campuran, maka tulisan ini akan menganalisis setiap unsur di atas.

1. Unsur "perkawinan antara dua orang yang di Indonesia". Unsur ini menjelaskan bahwa perkawinan campuran itu adalah termasuk perkawinan monogami. Unsur ini dapat dikatakan terpenuhi karena perkawinan antara WNI dan pengungsi asing tersebut dilakukan oleh dua manusia yang secara fisik berada di Indonesia. Perkawinan tersebut memang dilakukan oleh mereka yang tidak dalam ikatan perkawinan lain. Hal ini sangat jelas karena memang pengungsi asing yang berada di Indonesia memiliki keterbatasan pergerakan dan posisinya terbatas pada lingkup wilayah Provinsi di Indonesia.

2. Unsur "salah satu pihak berkewarganegaraan Indonesia". Unsur ini mempertegaskan bahwa pihak pria atau pihak wanita dalam perkawinan 
campuran harus warga negara Indonesia. Jika tidak ada pihak yang berkewarganegaraan Indonesia maka pernikahan ini tidak masuk dalam lingkup hukum Indonesia. Unsur salah satu pihak berkewarganegaraan Indonesia terdapat dalam perkawinan antara WNI dengan pengungsi asing.

3. Unsur "tunduk pada hukum yang berlainan, karena perbedaan kewarganegaraan". Perkawinan WNI dangan pengungsi asing tidak memenuhi insur ini, karena unsur ini menekankan kepada perbedaan hukum yang berlaku disebabkan perbedaan kewarganegaraan. Perbedaan hukum yang berlaku dalam perkawinan campuran bukan karena perbedaan golongan, suku bangsa, agama di Indonesia tetapi karena perbedaan kewarganegaraan. Dengan demikian perkawinan antara WNI dengan pengungsi asing tidak termasuk katagori ketentuan Pasal 57 UU No. 1 Tahun 1971. Karena perkawinan campuran yang dimaksud adalah perkawinan yang dilakukan antara dua orang yang tunduk pada hukum yang berlainan, hal ini berbeda pada kasus perkawinan WNI dengan pengungsi asing yang tidak tunduk pada dua ketentuan hukum yang berbeda melainkan perkawinan ini antara WNI dengan warga negara asing yang tidak mempunyai status kewarganegaraan atau yang disebut stateless person. Karena tidak memenuhi unsur tersebut maka untuk perkawinan tersebut Pasal 57 tidak dapat digunakan sebagai ketentuan hukum untuk melangsungkan perkawinan mereka.

Selain itu, pengungsi dengan status tanpa kewarganegaraan ini juga tidak dimungkinkan untuk mendapatkan status sebagai WNI hal ini disebabkan oleh tiga hal, yaitu:

1. Pengungsi asing tersebut terbentur oleh aturan dalam UU Kewarganegaraan dimana mereka tidak dapat memenuhi unsur mengenai tempat tinggal tetap dan pekerjaan tetap yang menjadi syarat untuk mendapatkan kewarganegaaraan Indonesia.

2. Pengungsi asing juga sulit memenuhi unsur dalam usaha mendapatkan kewarganegaraan Indonesia tersebut karena secara hukum pengungsi asing 
adalah imigran ilegal yang dikecualikan karena diberi hak untuk tetap tinggal di Indonesia secara sementara sebelum dpindahkan ke negara ketiga dengan kondisi tidak diperbolehkan untuk melakukan pekerjaan apapun yang mendapatkan upah.

3. Indonesia belum meratifikasi Konvensi Pengungsi 1951 sehingga Indonesia tidak memiliki kewajiban internasional untuk menjamin pengungsi memiliki hak untuk tempat tinggal dan pekerjaan.

Dengan demikian, dapat disimpulkan bahwa perkawinan yang telah dilakukan oleh WNI dengan pengungsi asing tersebut tidak dapat memenuhi kategori "Perkawinan Campuran" dalam UU Perkawinan. Hal ini membawa konsekuensi tidak dapat disahkannya perkawinan tersebut dalam hukum Indonesia serta tidak diperolehnya akta nikah sebagai alat bukti otentik dalam peristiwa perkawinan tersebut. Meskipun menurut peraturan perundangundangan yang berlaku perkawinan tersebut tidak mungkin dilangsungkan, akan tetapi pada kenyataannya, perkawinan tersebut tetap berlangsung atas dasar hukum agama saja atau sering disebut dengan pernikahan siri. Pernikahan secara agama atau siri ini dalam keadaan normal apabila ingin dilakukan pegesahannya menurut peraturan perundang-undangan yang berlaku maka dapat mengajukan permohonan itsbat nikah kepada Pengadilan Agama, yang mana dengan permohonan ini para pasangan akan memperoleh akta nikah. Namun mengenai masalah perkawinan siri yang dilakukan antara WNI dengan pengungsi asing dengan status tanpa kewarganegaraan ini perlu dibahas lebih lanjut.

\section{B. Pernikahan Siri antara WNI dan Pengungsi Asing Suatu Pemenuhan Syarat Sah}

Dengan melihat kenyataan pernikahan secara hukum agama (siri) antara WNI dan pengungsi asing, perlu dipastikan apakah perkawinan tersebut dapat dilegalkan dengan cara permohonan itsbat nikah kepada Pengadilan Agama. Hal ini dapat dilakukan apabila perkawinan tersebut telah memenuhi unsur-unsur 
hukum yang terdapat dalam Undang-Undang nomor 1 tahun 1974 tentang Perkawinan.

Hukum nasional di Indonesia yang mengatur perkawinan adalah UU No. 1 Tahun 1974. Dinyatakan dalam Pasal 1 bahwa perkawinan merupakan ikatan lahir dan bathin antara seorang pria dan seorang wanita sebagai suami isteri. Adapun tujuannya membentuk keluarga yang bahagia dan kekal atas dasar Ketuhanan Yang Maha Esa.

Perkawinan sebagai ikatan lahir merupakan hubungan hukum antara seorang pria dengan seorang wanita untuk hidup bersama sebagai suami isteri. Ikatan ini merupakan hubungan yang nyata, baik bagi yang mengikatkan dirinya maupun bagi orang lain maupun masyarakat (K. Wantjik Saleh, 1976: 14) Sebagai ikatan bathin, perkawinan merupakan pertalian jiwa yang terjalin karena adanya kemauan yang sama dan keikhlasan serta tidak adanya paksaan dari para pasangan calon mempelai untuk mengarungi bahtera rumah tangga sebagai suami isteri (K. Wantjik Saleh, 1976: 15).

UU No. 1 Tahun 1971 mensyaratkan beberapa persyaratan untuk yaitu terdiri dari:

1. Syarat material yaitu syarat yang mengenai diri pribadi seseorang yang melangsungkan perkawinan atau disebut juga syarat subjektif.

2. Syarat formil yaitu syarat mengenai tata cara atau prosedur pencatatan perkawinan menurut hukum agama dan undang-undang atau disebut juga syarat objektif (Abdulkadir Muhammad, 2000: 76).

Undang-Undang Nomor 1 Tahun 1974 telah menentukan bahwa Ketuhanan Yang Maha Esa harus menjadi dasar untuk membentuk keluarga (rumah tangga) yang bahagia dan kekal. Pasal 2 UU 1/1974 yang menyatakan bahwa:

(1) Perkawinan adalah sah apabila dilakukan menurut hukum masing-masing agama dan kepercayaannya itu.

(2) Tiap-tiap perkawinan dicatat menurut peraturan perundang-undangan yang berlaku.

Ketentuan tersebut menunjukkan bahwa perkawinan adalah sah apabila dilakukan menurut hukum masing-masing agama dan kepercayaan para calon 
mempelai. Kemudian yang wajib dilakukan adalah melakukan pencatatan atas perkawinan tersebut kepada pegawai pencatat nikah. Pencatatan ini wajib dilakukan dikarenakan pencatatan merupakan dasar untuk dikeluarkannya akta nikah yang mana sebagaimana kita ketahui bahwa akta nikah merupakan satu satunya alat bukti otentik dalam peristiwa perkawinan. Dari uraian tersebut maka dapat dinyatakan bahwa apabila terdapat perkawinan yang hanya dilakukan secara agama saja tanpa melakukan pencatatan, maka tidak dapat dikeluarkannya akta nikah. Dengan tidak adanya akta nikah maka apabila terdapat permasalahan dikemudian hari maka para pihak tidak dapat menuntut haknya selayaknya para pasangan lain yang menikah secara sah dan mempunyai akta nikah. Selain itu pula negara tidak dapat membantu dan melindungi hakhak para pasangan tersebut apabila timbul permasalahan diantara mereka dikemudian hari.

Pencatatan perkawinan adalah suatu pencatatan yang dilakukan oleh Pegawai Pencatat Nikah terhadap peristiwa perkawinan, yang kemudian oleh Pegawai Pencatat Nikah tersebut dituangkan dalam bentuk akta perkawinan. Dalam peristiwa perkawinan, akta perkawinan mempunyai peranan yang sangat penting. Tanpa adanya akta nikah dalam suatu perkawinan, maka perkawinan tersebut dapat dikatakan sebagai perkawinan yang tidak sah. Perihal pencatatan perkawinan telah diatur dalam peraturan perundang-undangan yang menjadi dasar hukumnya yaitu:

1. UU No. 1 Tahun 1974 tentang Perkawinan Pasal 2 ayat (2) dan PP No. 9 Tahun 1975 tentang Pelaksanaan Undang- Undang Perkawinan.

2. UU No. 23 Tahun 2006 tentang Administrasi Kependudukan.

3. Kompilasi Hukum Islam.

Sebenarnya perihal pencatatan perkawinan ini tidak diatur secara jelas apakah pencatatan ini merupakan syarat sahnya perkawinan atau syarat administratif saja. Namun, dalam Penjelasan Umum angka 4 huruf b UndangUndang Perkawinan tentang asas-asas atau prinsip-prinsip perkawinan dinyatakan:

"Bahwa suatu perkawinan adalah sah bilamana dilakukan menurut hukum 
masing-masing agamanya dan kepercayaannya itu; dan di samping itu tiaptiap perkawinan harus dicatat menurut peraturan perundang- undangan yang berlaku. Pencatatan tiap-tiap perkawinan adalah sama halnya dengan pencatatan peristiwa-peristiwa penting dalam kehidupan seseorang, misalnya kelahiran, kematian yang dinyatakan dalam surat- surat keterangan, suatu akta yang juga dimuat dalam daftar pencatatan".

Berdasarkan penjelasan Undang-Undang Perkawinan tersebut maka dapat dikatakan bahwa pencatatan perkawinan bukanlah merupakan faktor yang menentukan sah atau tidaknya suatu peristiwa perkawinan namun pencatatan perkawinan ini merupakan kewajiban administratif yang wajib dilakukan oleh para calon mempelai yang melangsungkan perkawinan. Pencatatan perkawinan ini sama halnya dengan pencatatan yang terjadi pada saat terjadinya kelahiran, kematian kehidupan seseorang.

Mahkamah Konstitusi telah mengeluarkan putusan terkait pencatatan perkawinan dalam putusan Nomor 46/PUU-VIII/2010 yang menyatakan bahwa kewajiban administratif pencatatan perkawinan mempunyai dua perspektif.

Pertama, dari perspektif negara. Diwajibkannya pencatatan perkawinan adalah dalam rangka menjalankan fungsi negara yang merupakan tanggung jawab negara, yaitu memberikan jaminan perlindungan, pemajuan, penegakan, dan pemenuhan hak asasi manusia terhadap rakyatnya. Negara dalam melakukan hal ini haruslah sesuai dengan prinsip negara hukum yang demokratis yang diatur serta dituangkan dalam konstitusi yaitu dalam Pasal 28 I ayat (4) dan ayat (5).

Kedua, pencatatan secara administratif yang dilakukan oleh negara berkaitan dengan akta nikah yang merupakan alat bukti yang sempurna. Perkawinan merupakan suatu perbuatan hukum yang penting dalam kehidupan seseorang dan implikasi yang akan terjadi dari akibat hukumnya pun sangat luas. Sehingga di kemudian hari dapat dibuktikan dengan alat bukti yang sempurna yaitu berupa akta nikah, maka negara dapat memberikan perlindungan dan pelayanan terhadap rakyatnya atas hak-hak yang timbul dari suatu peristiwa perkawinan. Dengan kata lain hak-hak yang timbul sebagai akibat perkawinan dapat terlindungi dan terlayani dengan baik jika memiliki akta nikah. 
Mengenai pencatatan perkawinan ini Hakim Maria Farida Indrati memiliki alasan yang berbeda (concurring opinion) terhadap putusan Mahkamah konstitusi Nomor 46/PUU-VIII/2010 yang menyatakan:

"Seturut dengan itu, ... sahnya perkawinan menurut agama dan kepercayaan tertentu tidak dapat secara langsung menjamin terpenuhinya hak-hak keperdataan istri, suami, dan/atau anak-anak yang dilahirkan dari perkawinan tersebut karena pelaksanaan norma agama dan adat di masyarakat diserahkan sepenuhnya kepada kesadaran individu dan kesadaran masyarakat tanpa dilindungi oleh otoritas resmi (negara) yang memiliki kekuatan pemaksa." (Putusan MK, 17 Februari 2012:39-40)

Berdasarkan pendapat tersebut menunjukkan dua arti penting pencatatan perkawinan yaitu agar mendapat perlindungan dari negara dan untuk menghindari kecenderungan inkonsistensi. Kecenderungan ini terjadi dalam penerapan ajaran agama dan kepercayaan secara sempurna atau utuh pada perkawinan yang dilangsungkan menurut agama dan kepercayaan tersebut. Dengan kata lain, dapat dikatakan bahwa untuk menghindari penyalahgunaan penerapan hukum agama dan kepercayaan dalam perkawinan secara sebagian saja, dalam arti hukum agama dan kepercayaan digunakan sebagai dasar hukum oleh pihak-pihak tertentu untuk memenuhi kepentingannya tanpa memperhatikan kerugian orang lain, maka dengan itu diperlukan pencatatan perkawinan.

Kepastian dan perlindungan hukum beserta akibat hukumnya diperlukan oleh suami istri dalam perkawinannya. Untuk itulah setiap perkawinan yang telah dilangsungkan harus dicatat. Kompilasi Hukum Islam (KHI) juga menegaskan pentingnya pencatatan perkawinan, namun tidak menyebutkan bahwa pencatatan perkawinan sebagai syarat formal untuk menentukan sah tidaknya ikatan perkawinan. Untuk menghindar dari tindakan psikologis dan sosiologis tersebut, perumus KHI memilih jalan keluar, dengan memperinci satu persatu fungsi pencatatan perkawinan dalam pelbagai pasal KHI (Arif Marsal \& Ryna Parlyna, 2015: 50)

Ketentuan Pasal 2 ayat (2) No. 1 Tahun 1974 menyatakan dengan jelas, setiap perkawinan harus dicatat menurut peraturan perundang-undangan yang 
berlaku. Kedua ayat dalam Pasal 2 No. 1 Tahun 1974 jika dihubungkan satu sama lainnya, maka dapat dianggap bahwa antara ayat (1) dan ayat (2) merupakan bagian satu kesatuan yang tidak dapat dipisahkan satu sama lain yang menentukan sahnya suatu peristiwa perkawinan. Sehingga terhadap perkawinan yang tidak dicatat, maka konsekuensinya tidak akan memperoleh akta nikah dan oleh negara perkawinan tersebut dianggap tidak pernah ada. Sehingga para pihak tidak akan mendapat kepastian hukum. Wanita dan anak yang dilahirkan dalam perkawinan tersebut biasanya merupakan pihak yang dirugikan (Abdurahman \& Riduan Syahrani, 1986: 16).

Akta nikah akan ditandatangani oleh kedua mempelai sesaat sesudah dilangsungkannya perkawinan, sebagaimana dinyatakan oleh Pasal 11 ayat (1) PP No. 9 Tahun 1975 tentang Pelaksanaan UU N0. 1 Tahun 1974 Akta nikah yang akan ditanda tangani tersebut telah disiapkan oleh Pegawai Pencatat. Selanjutnya akta nikah yang sudah ditandatangani oleh kedua mempelai akan ditanda tangani juga oleh dua orang saksi dan Pegawai Pencatat, dan ditanda tangani juga oleh wali nikah atau yang mewakilinya bagi yang melangsungkn perkawinan menurut agama Islam. Dengan telah selesainya penandatanganan akta nikah, maka perkawinan telah tercatat secara resmi. Dari aspek mengikatnya, secara yuridis fungsi pencatatan perkawinan berdasarkan UU 1/1974 jo. PP 9/1975 merupakan persyaratan supaya perkawinan tersebut mendapatkan pengakuan dan perlindungan hukum dari negara serta mengikat pihak ketiga (orang lain). Sementara itu dipandang dari aspek regulasi, pencatatan perkawinan mencerminkan suatu kepastian hukum, dengan ditentukannya bahwa suatu peristiwa perkawinan terjadi dibuktikan dengan adanya akta perkawinan. Sebagai konsekuensi lebih lanjut dalam pandangan hukum tidak ada perkawinan atau perkawinan adalah tidak sah apabila pelaksanaan perkawinannya tidak mengikuti tata cara dan pencatatan perkawinan (Trusto Subekti, 2010: 338). Dengan demikian dalam konteks dan berdasarkan UU 1/1974, pencatatan perkawinan merupakan syarat formal yang harus dilaksanakan agar suatu perkawinan diakui keabsahannya sebagai 
perbuatan hukum yang harus dijamin dan dilindungi oleh negara (Rachmadi Usman, 2017: 262).

Undang-Undang Administrasi Kependudukan juga mensyaratkan perlunya pencatatan perkawinan. Pasal 34 ayat (1) menentukan waijibnya melaporkan perkawinan yang sah berdasarkan peraturan perundang-undangan kepada instansi pelaksana. Sedangkan ayat (2) menentukan Pejabat pencatatan sipil akan mencatat laporan tersebut ke dalam register akta perkawinan dan menerbitkan kutipan akta perkawinan.

Pasal 5 dan Pasal 6 KHI menentukan bahwa masyarakat Indonesia yang beragama Islam yang telah melangsungkan perkawinan agar dicatat. Demikian juga pasangan WNI dan pengungsi asing pun harus memenuhi kewajiban pencatatan perkawinan.

a. Masyarakat Indonesia yang beragama Islam yang telah melangsungkan perkawinan agar dicatat demi mewujudkan ketertiban perkawinan;

b. Pegawai Pencatat Nikah melakukan pencatatan perkawinan sebagaimana diatur dalam UU 22/1946;

c. Perkawinan sah apabila dilangsungkan di hadapan dan di bawah pengawasan Pegawai Pencatat Nikah (PPN);

d. Perkawinan tidak sah atau tidak mempunyai kekuatan hukum jika dilakukan di luar pengawasan PPN.

Setelah mengetahui semua aturan terkait pencatatan perkawinan, selanjutnya penting untuk dianalisis apakah persyaratan formal perkawinan dalam bentuk pencatatan perkawinan yang telah dilakukan secara siri antara WNI dengan pengungsi asing dapat terpenuhi. Ketentuan Pasal 2 UU Perkawinan, menyebutkan unsur pencatatan perkawinan wajib sesuai dengan peraturan perundang-undangan yang berlaku. Lebih lanjut dalam Pasal 12 PP N0. 9 Tahun 1975 mengatur bahwa akta perkawinan memuat salah satunya adalah nama, tanggal dan tempat lahir, agama/kepercayaan, pekerjaan dan tempat kediaman suami/istri. Dengan demikian, perkawinan antara WNI dengan pengungsi asing tidak memenuhi ketentuan tersebut dikarenakan tidak adanya pekerjaan dan tempat kediaman (domisili). 
Pengungsi asing tidak memiliki kejelasan tempat tinggal sehingga tidak dapat diterbitkan akta perkawinan sesuai dalam Pasal 12 PP N0. 9 Tahun 1975, dan akibatnya perkawinan mereka tidak dapat diterbitkan Kutipan Akta Nikah sebagaimana ditentukan oleh Pasal 34 ayat (2) Undang-Undang Adminduk. Walaupun dalam pandangan hukum Islam perkawinan menurut agama (siri) merupakan perkawinan yang sah, tetapi dalam hukum Indonesia tidak demikian, karena tidak melalui proses pencatatan di Kantor Urusan Agama.

Ketentuan UU Perkawinan menentukan bahwa persyaratan dan prosedur pernikahan yang berlaku mengikuti prosedur dan persyaratan yang berlaku terhadap orang tersebut. Dengan kata lain, prosedur dan persyaratan pernikahan mengikuti status personal dari para mempelai. Sehingga warga negara Indonesia ataupun warga negara asing yang ingin melangsungkan pernikahan wajib memenuhi syarat-syarat yang ditentukan oleh hukum nasionalnya.

Lebih lanjut, keadaan tanpa kewarganegaraan memperlihatkan tidak adanya status personal dari calon mempelai. Hukum Indonesia sendiri belum mengakui adanya status personal seorang yang tidak berkewarganegaraan. Walaupun secara internasional Pasal 12 ayat (1) Konvensi 1951 menyatakan bahwa status personal seorang pengungsi diatur berdasarkan hukum dari negara tempat domisilinya, atau apabila tidak memiliki tempat domisili, dapat diatur berdasarkan ketentuan negara tempat tinggalnya. Namun, yang menjadi permasalahan adalah ketentuan tersebut tidak mengikat negara Indonesia, karena konvensi 1951 belum diratifikasi oleh Indonesia. Dengan tidak terikatnya Indonesia pada konvensi 1951, maka berakibat pengungsi tidak mempunya kejelasan mengenai status personalnya.

Hal ini menunjukkan kejelasan status personal seperti status kewarganegaraan seorang pengungsi merupakan syarat penentu dalam hukum Indonesia untuk dapat melangsungkan pernikahan yang sah. Status personal yang jelas dapat dijadikan sebagai dasar penentu syarat dan prosedur dari perkawinan.

Konsekuensi dari perkawinan antara WNI dengan pengungsi asing yang tidak atau tidak bisa dicatatkan adalah: 
1. Perkawinannya dianggap tidak sah.

2. Dalam pandangan hukum negara, meskipun sebuah perkawinan dilakukan menurut agama dan kepercayaan, perkawinan tersebut dianggap tidak sah. Anak yang dilahirkan dalam perkawinan tersebut hanya mempunyai hubungan perdata dengan ibu dan keluarga ibunya saja. Hal ini sesuai dengan Pasal 43 ayat (1) UU No. 1 Tahun 1974 tentang Perkawinan, yang menyatakan bahwa: "Anak yang dilahirkan di luar perkawinan hanya mempunyai hubungan perdata dengan ibunya dan keluarga ibunya"

3. Akibat lebih jauh dari perkawinan yang tidak tercatat adalah, baik isteri maupun anak-anak yang dilahirkan dari perkawinan tersebut tidak berhak menuntut nafkah ataupun warisan dari ayahnya.

\section{Penutup}

\section{A. Kesimpulan}

Perkawinan pada dasarnya harus dicatat agar terjamin kepastian dan perlindungan hukum bagi suami istri beserta akibat hukum. Pencatatan perkawinan merupakan suatu keharusan yang harus dipenuhi dalam perkawinan. Demikian juga halnya dalam perkawinan antara pengungsi asing dengan Warga Negara Indonesia. Seorang pengungsi, dalam hukum Indonesia tidak dapat melangsungkan perkawinan yang sah, hal ini disebabkan karena tidak adanya kejelasan status personal yang dapat dijadikan dasar penentuan syarat dan prosedur dari perkawinan tersebut, yaitu tidak adanya pekerjaan dan tempat kediaman (domisili). Pengungsi tidak memiliki kejelasan tempat tinggal sehingga tidak dapat diterbitkan akta perkawinan sesuai dalam Pasal 12 PP Nomor 9 Tahun 1975.

\section{B. Saran}

1. Indonesia dapat mengadopsi dua norma yang ada di Konvensi Pengungsi 1951 mengenai status domisili dan hak untuk menikah serta hak untuk bekerja. Norma tersebut dapat diakomodir dengan melakukan revisi atas UU Perkawinan dan UU Keimigrasian. Dengan 
demikian, hak dasar pengungsi asing untuk menikah dan bekerja dapat terpenuhi melalui kebijakan hukum tersebut.

2. Permohonan itsbat nikah kepada Pengadilan Agama dapat dilakukan berdasarkan Pasal 7 ayat 3e KHI. Hal ini mengingat bahwa perkawinan antara WNI dan pengungsi asing sebenaranya tidak terdapat halangan untuk dilangsungkannya perkawinan. Maka, dimungkinkan untuk mendapatkan pengesahan perkawinan yang pada akhirnya mendapatkan akta perkawinan yang merupakan satu-satunya alat bukti otentik dalam peristiwa perkawinan.

\section{Daftar Pustaka}

Abdurrahman dan Riduan Syahrani, Masalah-masalah Hukum Perkawinan di Indonesia. Alumni: Bandung, 1986.

Adiputera, Yunizar dan Atin Prabandari. Addressing Challenges and Identifying Opportunities for Refugee Access to Employment in Indonesia. Yogyakarta: Institute of International Studies, 2018.

Missbach, Antje. Troubled Transit: Asylum Seekers Stuck in Indonesia. Singapura: ISEAS-Yusof Ishak Institute, 2015.

Muhammad, Abdulkadir. Hukum Perdata Indonesia. Bandung: PT. Citra Aditya Bakti, 2000.

Saleh, K. Wantjik. Hukum Perkawinan Indonesia. Cet. 4. Jakarta: Ghalia Indonesia, 1976.

SUAKA. Hidup yang Terabaikan: Laporan Penelitian Nasib Pengungsi Rohingya di Indonesia. Jakarta: LBH Jakarta, 2016.

Fitria. "Perlindungan Hukum bagi Pengungsi di Negara Ketiga: Praktik Indonesia." Padjadjaran Jurnal Ilmu Hukum Vol. 2, No.1, 2015.

Kaharudin, Yuera Rizki, Sri Lestari Rahayu, Ayub Torry Satriyo Kusumo. "Homo Sacer: Anak-Anak Pengungsi Internasional Yang Lahir Di Indonesia Akibat Tidak Dipenuhinya Hak Untuk Mendapat Kewarganegaraan.” Jurnal Belli ac Pacis Vol. 3, No. 2, 2017. 
Marsal, Arif dan Ryna Parlyna, 2015, "Pencatatan Perkawinan: Antara Rukun Nikah dan Syarat Administratif.” Jurnal An-Nur, Vol. 4 No. 1, 2015.

Pelangi, Intan. "Perlindungan Terhadap Para Pencari Suaka Berdasarkan Undang-Undang Nomor 39 Tahun 1999 Tentang Hak Asasi Manusia.” Padjadjaran Jurnal Ilmu Hukum Vol. 4, No. 1, 2017.

Riadussyah, M. "Tanggung Jawab Indonesia sebagai Negara Transit bagi Pengungsi Anak Berdasarkan Hukum Internasional.” Jurnal Ius Quia Iustum Vol. 23, No. 2, 2016.

Subekti, Trusto. "Sahnya Perkawinan Menurut Undang-Undang Nomor 1 Tahun 1974 tentang Perkawinan Ditinjau dari Hukum Perjanjian.” Jurnal Dinamika Hukum, Vol. 10 No. 3, (2010).

Usman, Rachmadi. "Makna Pencatatan Perkawinan dalam Peraturan PerundangUndangan Perkawinan di Indonesia.” Jurnal Legislasi Indonesia, Vol. 14 No. 3, 2017.

Republik Indonesia. Undang Undang Dasar Negara Republik Indonesia Tahun 1945.

, Undang-Undang Nomor 1 Tahun 1974 tentang Perkawinan,

Lembaran Negara Tahun Nomor 1 Tahun 1974. Tambahan Lembaran Negara Nomor 3019.

, Undang-Undang Nomor 12 Tahun 2006 tentang Kewarganegaraan,

Lembaran Negara Tahun Nomor 63 Tahun 2006. Tambahan Lembaran Negara Nomor 4634.

, Undang-Undang Nomor 23 Tahun 2006 tentang Administrasi

Kependudukan. Lembaran Negara Tahun Nomor 124 Tahun 2006.

Tambahan Lembaran Negara Nomor 4674.

, Undang-Undang Nomor 6 Tahun 2011 tentang Keimigrasian.

Lembaran Negara Tahun Nomor 52 Tahun 2011. Tambahan Lembaran Negara Nomor 5216.

, Undang-Undang Nomor 16 Tahun 2019 tentang Perubahan atas

Undang-Undang Nomor 1 tahun 1974 tentang Perkawinan, Lembaran 
Negara Tahun Nomor 186 Tahun 2019. Tambahan Lembaran Negara Nomor 6401. , Peraturan Pemerintah Nomor 9 Tahun 1975 tentang Pelaksanaan Undang-Undang Nomor 1 Tahun 1974 tentang Perkawinan. Lembaran Negara Tahun Nomor 12 Tahun 1975. Tambahan Lembaran Negara Nomor 3050. Peraturan Dirjen Imigrasi No. 0352.GR.02.07 tahun 2016 tentang Penanganan Imigran Ilegal yang Menyatakan Diri sebagai Pencari Suaka atau Pengungsi. , Mahkamah Konstitusi R.I. Putusan No. 46/PUU-VIII/2010.

PBB. Convention Relating to the Status of Refugees. UNTS 189 (1951).

Cochrane, Joe. "Refugees in Indonesia: Hoped for Brief Stay, Many May Be Stuck for Life." (https://www.nytimes.com/2018/01/26/world/asia/indo nesia-refugees-united-nations.html), diakses 21 Maret 2020.

Nuramdani, Muhammad. "14 Wanita Medan Menikah dengan Pengungsi Rohingya." (https://www.liputan6.com/news/read/3088850/14-wanita-m edan-menikah-dengan-pengungsi-rohingya), diakses 21 Maret 2020.

Syukur, M. "Mengungkap Tabir Cinta Terlarang Para Pengungsi Asal Afghanistan di Pekanbaru." (https://www.liputan6.com/regional/read/39 18683/mengungkap-tabir-cinta-terlarang-para-pengungsi-asal-afghanis tan-di-pekanbaru), diakses 21 Maret 2020. 